\title{
Effect of Feeding Bt Cotton Seed Cake on the Cheese Chemical Composition and Sensory Characteristics
}

\author{
Adawi $\mathrm{AI}^{1 *}$, Jangool $\mathrm{RH}^{2}$ and Siddig $\mathrm{FS}^{3}$ \\ Faculty of Agricultural Sciences, Sudan \\ *Corresponding author: Adawi IA, Faculty of Agricultural Sciences, University of Gezira,Wad Medani, Sudan
}

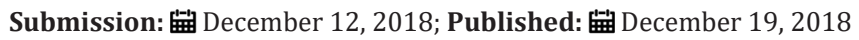

\begin{abstract}
This experiment was conducted in EL Nesheeshiba, Goat Research Center, University of Gezira Wad Medani Sudan. The objective of the experiment was to investigate; the effect of feeding goats on Bt cotton seed cake on cheese chemical composition and sensory characteristics. The results revealed that, there was significant differences $(\mathrm{P}<0.01)$ between cheese produced from feeding on Bt and Non-Bt cotton seed cake. With exception of acidity protein and ash were significantly $(\mathrm{P}<0.01)$ higher in cheese produced from milk goats fed on Bt cotton seed cake. Fat and total solid were significantly higher Non- Bt cotton seed fed goats. While there was no significant difference in sensory characteristics (color, flavor, taste and texture) between the cheese produced from Bt and Non-Bt milk. It was concluded that, feeding on Bt cotton seed cake significantly affect cheese chemical composition but not the sensory characteristics.
\end{abstract}

\section{Introduction}

Sudan is one of the African countries that grow cotton as a cash crop. Cotton production started in the country before the establishment of Sinnar dam in 1925. The crop contributed to different economical aspects, which included fiber export, oil production and produced seed cake after extraction of oil. Cottonseed meal is the by-product of oil extraction from cotton seeds. As a protein-rich feed, cottonseed meal is a common source of protein for ruminants, notably in cotton-producing areas such as India, China and the USA, where it is used as a partial substitute for soybean meal (O'Brien et al. 2005). Period of feeding Bt cotton seed cake witnesses increased milk production, surplus milk resulted from increased production, usually used for white cheese making. Due to introduction of Bt-cotton (genetically modified cotton) since 2012 , feeding seed cake and the animal products from feeding on it, began to be a matter of heated debate.

However currently most genetically enhanced plants in market place provide insect protection or herbicide tolerance, are being used as feed for livestock Calrk et al. [1].

Generally, reports on genetically modified crops as animal feed included for example, Bt -corn silage Shwan et al. [2], Calsimglia et al. [3] and Steink et al. [4], Soybean Tudisco et al. [5]. cotton seeds Singhal et al. [6] were cited. Many authors agreed on that, transgenic crops did not affect milk production and composition Shwan et al. [2], Singhal et al. [6] and Calsimglia et al. [3]. While some authors reported some effect on milk composition, for instance Steink et al. [4] reported higher contents of milk fat, lactose and proteins and Calsimglia et al. [3] found an increase in the contents of milk protein, lactose and SNF. However, Tudisco et al. [5] recorded a dramatic reduction on average protein content in the colostrum and reduced fat, when goats were fed on GM soybean.

Reference Jean et al. [7] reviewed the relationships between ruminant management and sensory characteristics of cheese. The authors concluded that ripened cheese characteristics depend on a lot of technological factors and when these factors are not controlled enough, it is difficult to reveal and interpret the effects of upstream factors (genetic, physiological or dietary). Among the various milk production conditions which may influence cheese characteristics, the floristic composition of forage used by animal. Reference Martin et al. [8] compared the different characteristics of Beaufort cheese made when herd successively grazed on different parts of the same highland pasture, while Buchin et al. [9] studied. The influence of the composition of the Alpine highland pasture on the chemical, rheological and sensory properties of Abundance cheese. In both experiments Martin et al. [8] and Buchan et al. [9], sensory characteristics varied according to the sward botanical composition. Difference concern texture and flavor (Abundance cheese) or only flavor (Beaufort cheese). Generally, in the available literature, effects of feeding on cotton seed cake either Bt or Non$\mathrm{Bt}$, on milk and cheese production and composition or sensory evaluation of these products is lacking. Therefore, this research was designed with the following objectives. To investigate the effect of Bt cotton seed cake on cheese chemical composition and sensory properties. 


\section{Materials and Methods}

\section{Location of the experiment}

\section{The study area}

The experiment was conducted in Nesheeshiba, Goat Research Center, University of Gezira, Wad Medani, Sudan.

\section{Experimental animals}

A total of six dairy Nubian goats of 1.5-year-old and 18 to $20 \mathrm{Kg}$ live body weight were used in the experiment The animals were divided into two group each group contain three goats.

\section{Feeding of animals}

The experimental animals were fed once a day on $600 \mathrm{~g}$ of concentrate diet containing, 34\% traditional cotton-seed cake (Hamid var.) or Bt cotton -seed cake, 17\% wheat bran, $45 \%$ sorghums and $4 \%$ mineral, in addition to green fodder and groundnut hay ad lib.

\section{Housing}

Each was animal identified by ear tag number, Each goat was housed in a separate iron cage $(1.5 \times 2 \mathrm{~m})$ fenced by iron bars and shaded by corrugated iron sheet. The cages were provided with water and feed trough.

\section{Health}

Health of the experimental goats was monitored daily by a veterinarian during the course of the study. At the beginning of the experiment body weight of each goat was recorded prior to their morning, feeding and watering and was again recorded after completion of four month of experimental feeding. Animal live weight was monitored every fifteen days and also body condition score of goat and kids.

\section{Milking schedule}

Goats were hand milked once a day at the morning. Each goat was milked in a separate bottle, weighed and recorded. Then stored in a separate tank, which was labeled as $\mathrm{Bt}$ or Non $\mathrm{Bt}$ at $3^{\circ} \mathrm{C}$ for further chemical analysis.

\section{Milking collection}

Milk was collected at month 3 of the feeding period of 4 month. During milking 12liter from each goat was taken in a clean bottle. Each herd milk was pooled for each of the groups The collected milk was frozen in Goat Research center, University of Gezira and cheese made from it. The sensory evaluation was carried out at the university of Gezira and chemical analysis in the laboratory of milk production of the faculty of Animal production in University of Khartoum, using the procedures of AOAC [10]. The cheese made was divided into two parts; one part was boiled and cooled for sensory evaluation. While the other part was used for cheese analysis.

\section{Chemical analysis}

Milk sample were analyzed for test chemical composition (fat, protein, SNF and lactose) by lacto scan (serial No 3694volt,
$50 / 60$ hertiz).

\section{Cheese making}

Cheese making was conducted in Goat Research center, Gezira University. The soft white cheese was made by the traditional method according to Ibrahim [11]. Where coagulation was done by rennet tablets [Chris Hansen's Laboratory, Copenhagen Denmark] that purchased from local market. After the cheese was processed it was cut into small cubes (about $50 \mathrm{~g}$ ) for sensory evaluation.

\section{Chemical analysis of cheese}

The moisture content in $\mathrm{Bt}$ and non Bt cheese was determined by the Method No. 926.08 of (AOAC 1990). Where samples were kept in oven at $103 \pm 5^{\circ} \mathrm{C}$ till the constant weight of dried cheeses is obtained. While fat content was determined by Gerber method as described by Marshall [12]. Total protein content was measured by Kjeldahl's method No. 20A: 1986 of [15]. However, ash content was determined by igniting the cheese sample according to method No. 935.42 of (AOAC 1990). (All the sample were determined in triplicates) [13].

\section{Sensory evaluation}

For sensory evaluation of milk, 30 university students who already have experience with milk and cheese were volunteered to perform the test.

Each student was given a cup of $100 \mathrm{ml}$ from each milk sample. The students filled a form containing the following properties:

Color, consistency, flavor, taste and overall assessment. The score allocated as follows:

$$
\begin{aligned}
& 4=\text { excellent } \\
& 3=\text { very good } \\
& 2=\text { good } \\
& 1=\text { fair } \\
& 0=\text { not acceptable }
\end{aligned}
$$

For cheese, the following characteristics were evaluated: Color, texture, flavor, taste and overall assessment. The same students were asked to perform cheese sensory evaluation.

The same scoring pattern of milk was also applied to cheese.

\section{Statistical analysis}

Means and differences between means of chemical composition of Bt and Non- Bt milk and cheese were performed using SPSS.

\section{Result and Discussion}

Anon significant different $(\mathrm{P}>0.05)$ was observed between the two experimental groups (Table 1) in the chemical composition of milk in fat, protein, S.N.F and lactose similar results were obtunding by (Singhal et al. [6] who reported no significance difference in milk composition produce from cows fed on cotton seed produce from Bt. Also, this result agreed with Castillo et al. (2001) while feeding BG II cottonseed and Folmer et al. (2002) on feeding Bt corn silage 
to lactating cows.

Table 1: Mean Percent of milk chemical composition produced from goats fed on Bt and Non-Bt cotton seed cake.

\begin{tabular}{|c|c|c|c|c|}
\hline & Bt-Cotton & $\begin{array}{c}\text { Non-Bt } \\
\text { Cotton }\end{array}$ & SE & Level of Sig. \\
\hline Fat & 4.7808 & 4.7867 & 0.176 & 0.373 \\
\hline Protein & 3.48 & 3.51 & 0.053 & 0.624 \\
\hline $\begin{array}{c}\text { Solid not fat } \\
\text { (S.N.F) }\end{array}$ & 9.04 & 8.93 & 0.159 & 0.515 \\
\hline Lactose & 4.81 & 4.79 & 0.084 & 0.84 \\
\hline
\end{tabular}

All the data presented in (Table 2) showed a significant differences $(\mathrm{P} \leq 0.05)$ between $\mathrm{Bt}$ and Non-Bt cotton seed fed goats Acidity, protein and ash contents were higher in Bt cotton seed cake fed goats, these results were on line with the work of Elobied et al. (2016) who reported a significant difference in chemical composition of cheese produced from dairy cows grazed on Bt and Non Bt cotton residues. Fat and total solid were higher in Non- Bt cotton seed cake fed goats, and this is also supported by the results obtained by Elobied et al. (2016).

Table 2: Percent chemical composition and acidity of cheese produced from goat's milk fed on Bt-cotton and Non-Bt cotton seed cake.

\begin{tabular}{|c|c|c|c|c|}
\hline & Bt-Cotton & Non-Bt Cotton & SE & Level of Sig. \\
\hline Acidity & 0.7 & 0.52 & 0.108 & 0.002 \\
\hline Fat & 16.13 & 19.96 & 0.124 & 0.001 \\
\hline
\end{tabular}

\begin{tabular}{|c|c|c|c|c|}
\hline Protein & 17.86 & 17.24 & 0.017 & 0.001 \\
\hline Total solid & 39.66 & 51.64 & 0.015 & 0.001 \\
\hline Ash & 9.46 & 6.7 & 0.145 & 0.001 \\
\hline
\end{tabular}

(Table 3) revealed that the results of the sensory evaluation of cheese produced from goat's milk fed on Bt and Non - Bt cotton seed cake were not significantly different between the two groups at $(\mathrm{P}>0.05)$ regarding color, flavor, taste and texture, estimated by Elobied et al. (2016).

Table 3: Sensory evaluation of chesses produced from goat fed on Bt-cotton and Non-Bt cotton seed cake.

\begin{tabular}{|c|c|c|c|c|}
\hline $\begin{array}{c}\text { Sensory Charac- } \\
\text { teristics }\end{array}$ & Bt-Cotton & $\begin{array}{c}\text { Non-Bt } \\
\text { Cotton }\end{array}$ & SE & Level of Sig. \\
\hline Color & 3.3 & 3.26 & 0.258 & 0.898 \\
\hline Flavor & 2.73 & 2.76 & 0.286 & 0.908 \\
\hline Taste & 2.6 & 2.76 & 0.329 & 0.615 \\
\hline Texture & 2.8 & 3.1 & 0.302 & 0.325 \\
\hline
\end{tabular}

(Figure 1) revealed that $89 \%(63+26)$ of the respondents indicated that the color of the cheese was excellent or very good in Non Bt fed group compared to $82 \%(67+15)$ of the respondents for Bt cotton seed cake (Figure 2). $77 \%$ of the respondents $(35+37)$ showed that the flavor of the cheese was excellent or very good in Non Bt cotton seed cake fed group compared to Bt cotton seed cake $72 \%(35+37)$, (Figure 1). (Figure 3) revealed that 78\% (34+44) of the respondents indicated that the taste of the cheese was excellent or very good in Non Bt fed group compared to 64\% (41+23) of the respondents for Bt cotton seed cake.

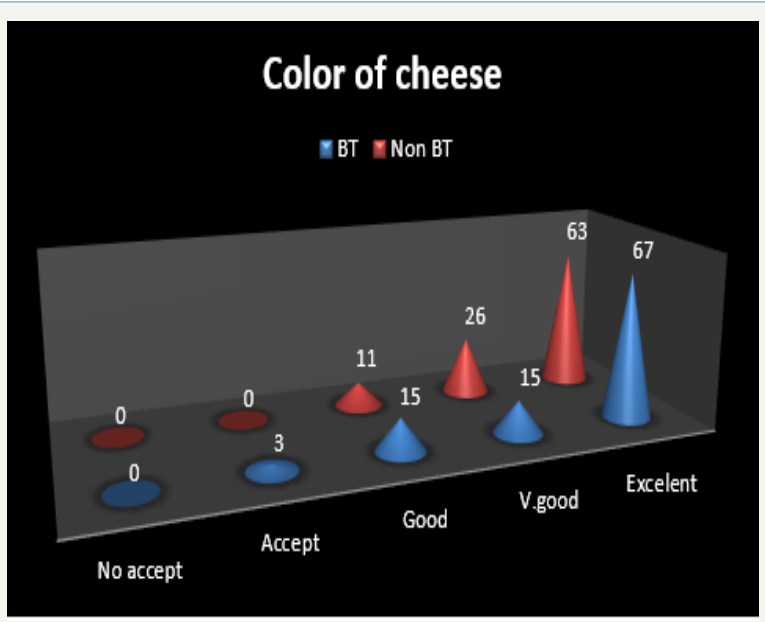

Figure 1: Percent assessment of color responded for cheese produced from Bt and non Bt cotton seed cake. 


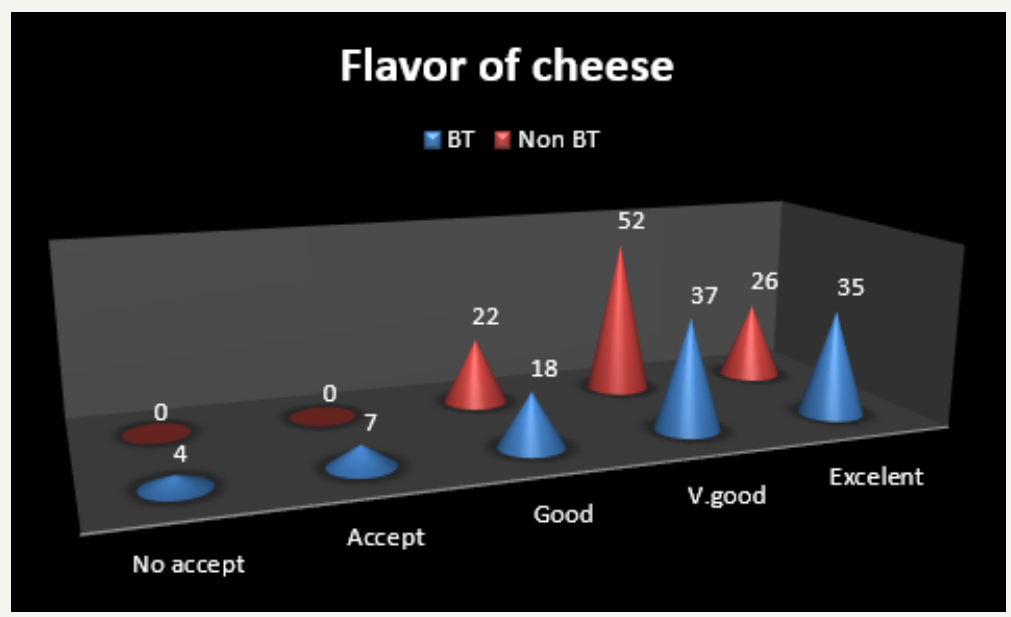

Figure 2: Percent assessment of flavor responded for cheese produced from Bt and non Bt cotton seed cake.

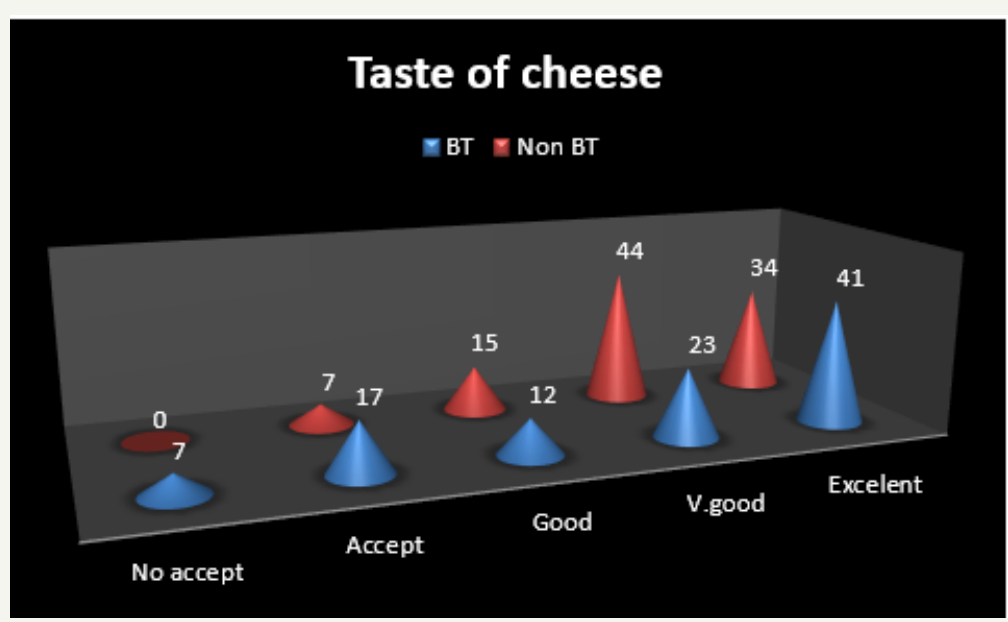

Figure 3: Percent assessment of taste responded for cheese produced from Bt and non Bt cotton seed cake.

\section{Conclusion}

It could be concluded that feeding on Bt cotton seed cake did not affect, cheese made from such milk. It similar to that made from milk produced from feeding on Non-Bt cotton seed cake in sensory properties. While it was significantly differed in chemical analysis. Whenever the safety of Bt -cotton crop residues as animal feed is proven, utilization of the milk produced from it for cheese making may be one of the promising marketing channels. Finally, more efforts for investigation of Bt-cotton crop residences as animal feed are urgently needed. However, cotton seed cake support thousands of animal units in Africa and Asia. Also, the products of animals fedd on Bt- cotton seed cake needs to be checked for Bt-toxin.

\section{References}

1. Clark JH, Ipharraguerre JK (2001) Livestock performance: Feeding biotech Crops. Dairy Sci 84(supp): E9- E18.

2. Shwan S, Donkin (2000) Performance of dairy cattle fed specialty corn hybrids. Paper presented at the Purdue Forage day, pp.1-11.

3. Calsamiglia S, Hernandez B, Hartnell GF, Phipps R (2007) Effect of corn silage derived from genetically modified variety containing two transgenes on food intake, milk production and composition and absence of detectable transgenic deoxyribonucleic acid in milk in holstein dairy cows. J Dairy Sci 90(10): 4718-4723.

4. Steinke K, Gaertner P, Paul V, Wiedemmann S, Ettle T, et al. (2010) Effect of long term feeding of genetically modified corn (event MON810) on the performance of lactating dairy cows. J Anim Physiol Anim Nutr (Berl) 94(5): 185-193.

5. Tudisco R, Cutrignelli MI, Moniello G, Grossi M, Mastellone V, et al. (2015) Genetically modified soybean in goat diet: Influence on kid performance. Small Ruminant Research 126 (supp 1): 67-74.

6. Singhal KK, Taygi AK, Rajput YS, Singh M, Hartell GF, et al. (2006) Effect of feeding cotton seed produced from Bollgard II cotton on feed intake, milk production and composition in lactating cross-bred cows. In: Proceedings of the $12^{\text {th }}$ Animal Science Congress of the Asian- Australian of animal Production Societies (AAAP), Abast, Bussan, South Korea, p. 757.

7. Jean BC, Agnés DB, Martin B, Pirisi A (2004) Relationships between ruminant management and sensory characteristics of cheese: A review. Lait 84(3): 221-241.

8. Martin B, Buchin S, Hauwuy A (2001) Effect de la nature botanique des pâturages sur les caractéyistiques sensorielles du formage de Beaufort. In: Formaggi d'Alpeggio e Loro de Tracciabilita, ANFOSC (edn), Potenza, Italy, pp. 230-237.

9. Buchin S, Martin M, Dupont D, Bornard A (1999) Influence of the composition of Alpine highland pasture on the chemical, reological and sensory properties of cheese. Journal of Dairy Research 66(4): 579-588. 
10. AOAC (1990) Association of official analytical chemists. Official Methods of Analysis.

11. Ibrahim AE (2009) Chemical preservation of milk in the Sudan. Sudan J Food Sci Technol 21: 31-32.
12. Marshall RT (1992) Standard methods for the examination of dairy products. $16^{\text {th }}$ edn. Washington, DC: American Public Health Association.

13. (1986) International IDF Standard 20A Milk. Determination of Nitrogen Content (Kjeldahl Method) and Calculation of Crude Protein Content. (C) (9) Creative Commons Attribution 4.0

For possible submissions Click Here

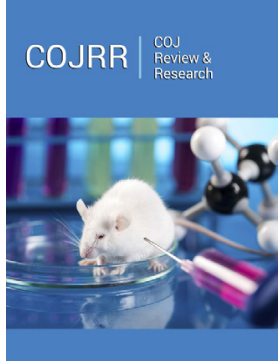

\section{COJ Reviews \& Research}

Benefits of Publishing with us

- High-level peer review and editorial services

- Freely accessible online immediately upon publication

- Authors retain the copyright to their work

- Licensing it under a Creative Commons license

- Visibility through different online platforms 